\title{
Strategies of Business English Translation from the Perspective of Functional Equivalence
}

\author{
Hui Fan \\ School of Foreign Studies, Yangtze University, Jingzhou, China \\ Email: fanhui@yangtzeu.edu.cn
}

How to cite this paper: Fan, H. (2018). Strategies of Business English Translation from the Perspective of Functional Equivalence. Advances in Literary Study, 6, 19-29. https://doi.org/10.4236/als.2018.61003

Received: November 28, 2017

Accepted: January 20, 2018

Published: January 23, 2018

Copyright $\odot 2018$ by author and Scientific Research Publishing Inc. This work is licensed under the Creative Commons Attribution International License (CC BY 4.0).

http://creativecommons.org/licenses/by/4.0/

\begin{abstract}
The paper begins with the introduction of Nida's functional equivalence theory, which is introduced to be reasonable guidance for business translation. Under the theory, plenty of examples and cases are quoted and analyzed, achieving functional equivalence in meaning, style and culture at the word level, the sentence level and the discourse level. This result indicates that $\mathrm{Ni}$ da's theory of functional equivalence can be best applied in business English translation and functional equivalence can be achieved.
\end{abstract}

\section{Keywords}

Functional Equivalence, Strategies, Nida, Translation

\section{Introduction}

In the new era of globalization of the 21st century, business English displays its overwhelming strength. It is reported in statistics that nearly $90 \%$ of those who use English as their first language or second language approach daily with Business English (Liao \& Mo, 2005).

During last decades, we have seen China conducting an increasing number of international trade business with other countries. Business English translation is an essential tool for the trading activities between Chinese businessmen, whose mother tongue is not English, and their counterparts from English-speaking countries. The theories and principles of business English translation have been improved greatly in the past. At present, more and more people start learning business English especially business English translation.

One authoritative book Teaching Business English (Ellis \& Johnson, 2005) is written for teachers, trainers and course organizers in the field of Business English to consider a move into it. It gives background to the business learner's world and strategies for approaching the training task, focusing on the learner's 
professional knowledge and experience. Chinese scholars focus on the translation of business English and many books have been written to teach business English translation during these years, for example, Commercial English Translation by Yu Fulin and Wang Zhanbin (Yu \& Wang, 2003), Practical Translation Course of Business English by Li Chao (Li, 2003). And Professor Liao Ying published several books concerning business translation (Liao, 2003).

There are so many books on the background of business contexts and basic knowledge of the trading process. However, the major purpose of this paper is to absorb the strength of Nida's functional equivalence theory and apply it to translation of business English. Since the applicability of this theory to general literary translation has been examined by many scholars, the author attempts to explore its application to business field: business English translation, which owns totally different manners and styles. Strategies are put forward for translation study of business English, by which some reference material and governing methods are offered.

\section{Nida's Functional Equivalence}

Nida's most notable contribution to translation theory is Functional Equivalence, which is also well known as Dynamic Equivalence. Nida's Functional Equivalence theory is often held in opposition to the views of philologists who maintain that an understanding of the source text (ST) can be achieved by assessing the inter-animation of words on the page, and that meaning is self-contained within the text (i.e. much more focused on achieving semantic equivalence).

This theory, along with other theories of correspondence in translating, are elaborated in his essay where Nida states that "no two languages are identical, either in the meanings given to corresponding symbols or in the ways in which symbols are arranged in phrases and sentences, it stands to reason that there can be no absolute correspondence between languages. Hence, there can be no fully exact translations." (Nida, 1964) While the impact of translation may be close to the original, there can be no identity in detail.

Nida then sets forth the differences in translation, as he would account for it, within three basic factors:

1) The nature of the message: in some messages the content is of primary consideration, and in others the form must be given a higher priority.

2) The purpose of the author and of the translator: to give information on both form and content; to aim at full intelligibility of the reader so he/she may understand the full implications of the message; for imperative purposes that aim at not just understanding the translation but also at ensuring no misunderstanding of the translation.

3) The type of audience: prospective audiences differ both in decoding ability and in potential interest.

Nida brings in the reminder that while there are no such things as "identical equivalents" in translating, what one must seek to do is to find the "closest natu- 
ral equivalent". Here he identifies two basic orientations in translating based on two different types of equivalence: Formal Equivalence (F-E) and Dynamic Equivalence (D-E).

F-E focuses attention on the message itself, in both form and content. Such translations then would be concerned with such correspondences as poetry to poetry, sentence to sentence, and concept to concept. Such a formal orientation that typifies this type of structural equivalence is called a "gloss translation" in which the translator aims at reproducing as literally and meaningfully as possible the form and content of the original.

The principles governing an F-E translation would then be: reproduction of grammatical units; consistency in word usage; and meanings in terms of the source context.

D-E on the other hand aims at complete "naturalness" of expression. A D-E translation is directed primarily towards equivalence of response rather than equivalence of form. The relationship between the target language receptor and message should be substantially the same as that which existed between the original (source language) receptors and the message.

The principles governing a D-E translation then would be: conformance of a translation to the receptor language and culture as a whole; and the translation must be in accordance with the context of the message which involves the stylistic selection and arrangement of message constituents. Dynamic equivalence includes four aspects:

1) Lexical equivalence: The meaning of a word lies in its usage in language. In translation practice, what confuses us is how to find the corresponding meaning in the target language.

2) Syntactic equivalence: It deals with sentence structure and grammar, such as number, gender, tense, which is more complicated than lexical equivalence.

3) Textual equivalence: It aims to achieve passage equivalence, in which language is not the unique element to be considered, how the language represents meaning and performs its function in a specific context matter most.

4) Stylistic equivalence: Different stylistic works have different language features. Achieving stylistic equivalence needs good mastery of both source language and target language. Different language styles represent different culture elements.

Among these four aspects, Nida believes that the meaning is the most important, followed by the form (Nida, 1986).

From one Language to another, the expression dynamic equivalence was replaced by functional equivalence. But essentially there are not too many differences between the two concepts.

\section{Strategies of Business English Translation from the Perspective of Functional Equivalence}

\subsection{Strategies for Achieving Functional Equivalence in Meaning}

The most important principle of business English translation from the perspec- 
tive of functional equivalence is that two kinds of languages should be equivalent in the meaning. The process of translation from original language to target language by three stages as Nida said: firstly, builds a code; secondly, operates the code; and thirdly, how to relate the two language codes (Nida, 1964).

Nida's functional equivalence theory requests that the target reader has the same effect on the translation with the original reader on the original version. As Newmark said, "Translation attempts to produce on its readers an effect as close as possible to that obtained on the readers of the original." (Newmark, 2006)

In business English translation from the perspective of functional equivalence, translators pay attention to aim at the equivalent language rather than the same language. In this sense, translators are supposed to remember that the most important thing for business English translation is the meaning of the original version.

In order to achieve functional equivalence in meaning, we should reach functional equivalence in two aspects: lexical level and syntactical level.

\subsubsection{Strategies at Lexical Level}

1) Selecting the word's meaning based on part of speech

As is known to us, many English words have different parts of speech. Different parts of speeches often have different meanings. When we translate business English, it is better to identify the part of speech of the word in the sentence, and then select the appropriate meaning based on part of speech of this word. There are some examples as followed:

1a. If a particular cargo is partially damaged, the damage is called particular average.

1b. 假如某批货是部分受损, 我们称之为 “单独海损”。

2a. It's obvious that the products are below average quality.

2b. 很明显, 这批产品的品质低于平均水平。

As for "average", in the previous sentence it is a noun in which "particular average” means “单独海损” (a partial loss in marine insurance). However, in the next sentence it is an adjective, which means “平均的” (the usual level or amount for most people or things).

3a. We had like to inform you that our counter sample will be sent to you by DHL by the end of this week. After you have confirmed it ASAP, we can start mass production.

3b. 很高兴通知您, 我方的回样将于本周末用敦豪特快快递给您。请尽快 确认, 以便我们开始评批量生产。

4a. Payment will be made by a $100 \%$ confirmed, irrevocable Letter of Credit, available by sight draft.

4b. 付款方式为 $100 \%$ 即期，保兑，不可撤消信用证。

As for "confirmed", in the first sentence it is a verb, which means “确认” (to make a position, an agreement); in the second sentence it is an adjective, which means “保兑的” (underbond).

2) Taking account of context and lexical collocation

Taking account of context and lexical collocation is also an important strategy 
to reach equivalence in the meaning at lexical level. When we translate business English materials, context and lexical collocation influence the word's meaning a lot. A word in English often contains more than one meaning, but there is only one meaning in the specific context. And this meaning of existence depends on its context or lexical collocation. Therefore, whatever we translate business English to Chinese or translate Chinese to English, it is necessary to determine the target language phrase match according to the content or style adjacent. There are some examples below:

5a. Routine duties of the joint venture company are to be discharged by the general manager appointed by the Board of directors.

5b. 董事会任命的总经理，负责履行合营公司的日常职权。

6a. Party B agrees that the expiration of this license shall not discharge party B from its obligation.

6b. 乙方同意在许可证到期之日前不免除乙方应尽的义务。

As for “discharge”, it means “履行” (carrying out one’s duty) in the first sentence, and “免除” (releasing one party from the terms of a contract) in the second one.

7a. We are glad to say that just now the market is in a very strong position.

7b. 我们高兴地告知你方, 现在行情上涨。

8a. Cotton and silk blouses made in China enjoy a good market in North Africa.

8b. 棉质与丝质女衬衫在北非销路很好。

As for “market”, it means “行情” (market quotation) in the first sentence. When it appears in the phrase "a good market" in the second one, we will translate “销路好” (good selling).

9. 基本条款 condition clause

基本价格 base price

基本工资 basic wage

基本建设 capital construction

In Chinese, “基本” is used very frequently and widely, and contains too many meanings. Many Chinese phrase about “基本” is conventional lexical collocation. In different English context, we should use different English words to describe them.

3) Negative

There are huge differences in the expression style between Chinese and English. Therefore, it is not the same when Chinese and English express their own negative meaning. It is necessary for translators to translate some affirmative sentences into negative ones or on the contrary. There are some examples below:

10a. I am sorry to tell you that your offer failed to arouse any interest among our clients.

10b. 很遗憾你们的报盘没有引起我们客户的兴趣。

\subsubsection{Strategies at Syntactic Level}

When translating sentences in business English, based on the syntactic features 
of business English, we should firstly pay attention to translate long sentences, passive voice sentences and established sentence patterns.

1) Division for long sentence

Because of the features of business English, long sentence takes a large proportion in business English. Here the author stresses that division is to divide the long sentence into several independent short sentences which are connected by logic relations and context, not by grammar marks according to Chinese practice. What is the most important is that translators must understand the original language clearly. And then it is possible for them to translate a long English sentence into short Chinese sentences. There are some examples below:

11a. During the 1950s China exported agricultural products to the USSR and East European countries in return for manufactured goods and the capital equipment required for the country's industrialization program which places emphasis on the development of heavy industry.

11b. 20 世纪 50 年代, 中国向前苏联和东欧各国出口农产品。此种做法用以 换取制成品和国家的工业化所要求的资本设备。

In this case, this long English sentence is divided into two short Chinese sentences based on Chinese practice. And the Chinese will understand the meaning completely.

12a. In the event that one or both parties fail to fulfill or perform any of the duties provided hereunder on account of Force Majeure, the party (or both parties) shall inform the other party (or each other) of the matter immediately and provided the case is duly verified by the competent authorities, they may delay in performance of or make non-performance of the relevant contract obligations herein.

12b. 如果一方或双方因人力不可抗拒的原因，未能完成或履行合同下的相 关条款，应及时向对方告知情况。如果取得合法机关的有效证明，允许延期 履行或不履行合同中的相关义务。

13a. The growth of foreign trade was disrupted again during the Cultural Revolution when agricultural and industrial production fell sharply and transportation constraints became serious.

13b. 在文化大革命期间，外贸的增长又一次被打断了。当时农业和工业生 产急剧下降，运输管制变得加严峻。

14a. That was a principle that Apple tragically failed to understand when it backed off from licensing its graphic computer interface, assuring that its market share would be savaged by Microsoft's more open Windows operating system.

14b. 可悲的是, 苹果公司未能理解这一点。它放弃了它的图形电脑界面的 销售许可, 因为担心自己的市场份额会被微软更开放的视窗操作系统无情地 侵占。

In these four cases, the translator divides the long and complex sentences into short Chinese sentences to help the reader to better understand the meaning.

2) English Passive voice into Chinese active voice or non-subject sentence

According to Chinese practice, Chinese use more active voice and non-subject than passive voice. A translator should pay attention to such situation. For ex- 
amples:

15a. More goods needed to be produced so more jobs and profits were created.

15b. 需要生产更多的产品以创造更多的就业机会和利润。

16a. Broadway Vehicles is committed to the effective implementation of its equal opportunities policy.

16b. 百老汇汽车公司承诺将有效执行公司的机会均等政策。

17a. Our products are manufactured from completely natural ingredients and we do not utilize any artificial additives at all.

$17 \mathrm{~b}$. 我们的产品全部是用天然原料制成, 没有使用任何人工添加剂。

In these cases, the translator changes English passive voice into Chinese non-subject sentence based on Chinese practice.

3) Use settled sentence for established sentence patterns

In business English, there are many sentence models, which can improve the efficiency of business communication and make one party feel the other party's politeness.

18a. Please accept our thanks for the trouble you have taken.

$18 \mathrm{~b}$. 有劳贵方, 不胜感激。

19a. We will spare no efforts in endeavoring to be of service to you.

$19 b$. 我方将不遗余力为贵方效劳。

20a. It will be greatly appreciated if you will kindly send us your samples.

20b. 如承惠寄样品, 则不胜感激。

21a. We tender you our sincere thanks for your generous treatment of us in this affair.

21b. 对贵方在此事中的慷慨之举, 深表感谢。

22a. We should be grateful for your trial order.

22b. 如承试订货, 不胜感激。

\subsection{Strategies for Achieving Functional Equivalence in Style}

Nida thought that functional equivalence in the meaning and functional equivalence in style are the two main factors for business English translation. A successful translator needs to reach equivalence both in meaning and in style.

After analyzing functional equivalence in the meaning, the next thesis will analyze how to reach style equivalence based on the stylistic features of business English.

\subsubsection{Translated Text Should Be Formal}

Qing Xiubai proposes five varieties of style. They are: the frozen style, the formal style, the consultative style, the casual style and the intimate style. We know business English belongs to formal style, so in order to achieve equivalence in style, the target language should be formal ( $\mathrm{Li}, 2010)$.

23a. This contract is made by and between the buyer and the seller, where by the buyer agrees to buy and the seller agrees to sell the under-mentioned commodity according to the conditions stipulated below: 
23b. 买卖双方同意按下列条款购买出售所列商品并签订本合同。

24a. The contract is made out in English and Chinese languages in quadruplicate, both texts being equally authentic, and each Party shall hold two copies of each text.

24b. 本合同用中英两种文字完成，一式四份。双方执中英文本各一份，一 式两份, 且两种文本具有同等效力。

25a. Any failure or delay in the performance by either party hereto of its obligations under this Agreement shall not constitute a breach hereof or give rise to any claims for damages if and to the extent that it is caused by occurrences beyond the control of the party affected, including, but without limiting the generality of the forgoing, acts of governmental authority, acts of god, strikes or concerted acts of workmen, fires, floods, explosions, wars, riots, storms, earthquakes, accidents, acts of a public enemy, rebellion, insurrection, sabotage, epidemic, quarantine restrictions, shortages of labor, materials or supplies, failures by contractors or subcontractors, transportation embargoes, failures or delays in transportation, rules, regulations, orders or directives of any government or any state, subdivision, agency or instrumentality thereof or the order of any court of competent jurisdiction.

25b. 本合同任何一方未能按合同履约或延误履约之行为, 如果是由于发生 该方无法控制的事件所造成的，则在此范围内不构成对本合同的违反，也不 会导致任何索赔要求。在并不限制上述事件有其广泛意义的前提下，此类事 件包括: 政府的行为, 自然界的行为, 工人罢工或联合行动、火灾、水灾、 爆炸、战争、暴乱、风暴、地震、事故, 社会公敌的行为, 叛乱, 起义, 破 坏, 传染病, 隔离控制, 劳动力、原材料或物质短缺, 承包者或分包者为履 行, 禁运、运输方面未能履约或延误, 任何政府或国家、下属各部门、机构 或组织的条例、规定、命令或指示，任何有管辖权的法院的命令。

In international trade, in order to avoid confusion and unnecessary ideological controversy between two parties, the legal documents should be very formal.

\subsubsection{Translated Text Should Be Courteous}

Courtesy is one of the important stylistic features of practical business English. In fact, courtesy plays an important role in the whole business process. It is vital to help to give a good impression on each other, and to deepen a friendship, and to reinforce a business relationship or establish new business. In order to convey two party's sincere, translator should keep this sincere in the translation. For example:

26a. We should be grateful if you would revise the invoice and let us have a correct copy.

26b. 如贵方能修订发票，并回寄更改后的文本，我方将不胜感激。

27a. We wish we could accept your counter-offer but unfortunately the price quoted by us is quite realistic, we cannot do so.

27b. 我们也希望能接受你方的还盘, 但令人遗憾的是报给你方的价格已经 触底, 我们确实无法同意还盘。

28a. Would you please send us your catalogue together with detailed offer? 
28b. 请把你们的样品目录和详细报价寄给我们好吗?

29a. We hope to enlarge our trade with your country and intend to grant you a $4 \%$ discount.

29b. 我们希望扩大与贵国的贸易, 并准备给你方百分之四的折扣。

30a. I am really sorry that our products can hardly satisfy your requirement.

30b. 对我方产品不能满足你方要求, 甚感报歉。

In international trade, in order to maintain relationship between two parties, keeping courtesy is an important strategy.

\subsection{Strategies for Achieving Functional Equivalence in Culture}

In the paper above, the author discussed how to achieve functional equivalence in meaning and in style. But those are basic requirements in business English translation. Functional equivalence in culture is at a deeper level. As a translator, we are supposed to pay special attention to cultural factors in the original language text and strives to preserve in the target language text from the original cultural messages as much as possible.

It is very difficult to achieve functional equivalence in culture totally. After all, English and Chinese have too many differences. In order to try the best to achieve functional equivalence in culture, translators must have a good knowledge of history and background of these two languages.

31a. Make yourself heard (Ericsson Mobile phone).

31b. 理解就是沟通。

In example 31, in English-speaking countries, individualism is greatly valued. So in English version, obviously the word "yourself" is stressed. However, in Chinese culture, individualism is always connected with self-centeredness. For the public, it is important that people are supposed to communicate with each other and understand each other in China. Therefore, culture differences result in differences of selecting words.

32a. Keep Dry.

32b. 切勿受潮。

Packaging is an important section of business and trade activities. Packing terms can give appropriate guidance for people in the operating process to load and unload, to transport, to store and to sell. Therefore, translation of packaging terms is essential. In English-speaking countries, people are accustomed to use imperative sentences. In China, however, for important events, people are accustomed to use negative sentence for emphasis.

33a. Apple think different!

33b. 苹果电脑, 不同凡想!

In 1997, Steve Jobs returned to Apple as CEO and introduced the famous advertisement "Apple Think Different" to pass Apple's values. Who thinks different are those with independent thinking; those who have the courage to abandon maverick vision; those who are willing to learn new things with an empty mentality; those who are willing to pursue personal goals and make unremitting ef- 
forts of the people; those people who want to change the world. Actually, "Thinking different" has become pursuit of American youth nowadays. As for them, thinking different from others is really wonderful.

However, in China, people always tend to compete with others. They always want to be better than others. In Chinese, “不同凡想” means “your thought is better than others" ordinary thought". This version is favored by Chinese people.

\section{Conclusion}

While functional equivalence theory has been introduced into China for a not very long time, it has aroused much discussion particularly in the realm of business English which can be perfected and improved from either theoretic or practical perspective. The specific linguistic traits of business English make it more challenging to adopt functional equivalence to guide its translation. The paper combines the language features of business English with the study of business English translation. It explores a systematic analysis from the functional view and proposes several strategies in the business translation practice, which indicates that Nida's theory of functional equivalence can be best applied in business English translation and functional equivalence can be achieved. On the other hand, equivalence theory still needs to be improved. The significance of this paper is to make contributions to the research on business English and business English translation and be of some help to those whose profession is business English teaching or those who are intending to work in this field. Nevertheless, the author feels that the limitations of this study are inevitable owing to insufficient experience in business translation as well as researches on theory comparison. There are still a shortage of deep analysis and explanation of functional equivalence. This study fails to set out every micro part of functional equivalence. Moreover, the functional equivalence theory possesses merits and demerits, in which the paper doesn't enumerate its demerits as the study is applied with the strength of the theory.

\section{References}

Li, C. (2003). Practical Translation Course of Business English. Shanghai: Fudan University Press.

Li, J. (2010). Business English Translation Guided by Functional Equivalence Theory. Changchun: Changchun University of Science and Technology.

Liao, Y. (2003). Practical English for Foreign Trade Communication. Wuhan: Huazhong University of Science \& Technology Press.

Liao, Y., \& Mo, Z. S. (2005). Researches for Language and Translation on International Business English. Beijing: China Machine Press.

Ellis, M., \& Johnson, C. (2005). Teaching Business English. Oxford: Oxford University Press.

Nida, E. A. (1964). Toward a Science of Translating. Leiden: E. J. Nrill.

Nida, E. A. (1986). A Functional Approach to Problems of Translation. Foreign Language 
Teaching and Research.

Newmark, P. (2006). About Translation. Foreign Language Teaching.

Yu, F. L., \& Wang, Z. B. (2003). Commercial English Translation. Beijing: China Commercial and Trade Press. 